\title{
A könnyen érthető kommuniká- ció mint innováció megjelenése az integrált nevelési-oktatási folyamatban
}

\begin{abstract}
A tanulmányban - szemle jelleggel - egy falusi, tanulásban akadályozott tanulók számára inkluzív nevelést biztosító általános iskolában bevezetett módszertani innováció bemutatására kerül sor. Célunk annak szemléltetése, hogy a többségi és a tanulásban akadályozott tanulók együttoktatása hogyan valósítható meg könnyen érthetö oktatási segédanyagok készitésével. A fejlesztés eredményeként átalakulhat az együttnevelést segítö pedagógus kompetenciája: a tanuló osztályközösségből történő kiemeléséről és egyéni fejlesztéséröl a hangsúly áthelyeződik a többségi pedagógussal történő együttműködésre, a többségi pedagógus által az osztálytermi differenciálást lehetővé tevő könnyen érthető oktatási segédanyagok létrehozására. A tanulmányban kitérünk a tanulók tudásmérését szolgáló eszközök adaptálásának szükségességére is. A módszer alkalmazásába bekapcsolódó pedagógusok és tanulók véleménye, valamint szisztematikus megfigyeléseim alapján úgy tủnik, hogy a könnyen érthető kommunikációval a tanulók jól motiválhatók olvasási feladatok elvégzésére, eredményesebbekké válnak, fokozható a teljesítményük.
\end{abstract}

Kulcsszavak: könnyen érthetö oktatási segédanyag, demokratikus jogok, esélyegyenlőség, inkluzív nevelés, együttnevelést segitő pedagógus kompetenciája, együttmüködés, innováció

Jelen tanulmányban egy falusi, tanulásban akadályozott tanulók együttnevelésére vállalkozó integráló iskolában megvalósított innovációt mutatok be. Az iskola tanáraival arra vállalkoztunk, hogy elkészítjük a tanulásban akadályozott tanulók számára sokszor nehezen értelmezhető iskolai tankönyvek szövegének könnyen érthető változatát, majd ezeket a tanórai differenciálás eszközeként a szaktanárok aktív szerepvállalása mellett bevezetjük a tanórákon. A fejlesztés eredményeként lehetőség nyílik arra is, hogy lassan megváltozzon az együttnevelést segítő pedagógus kompetenciája: az osztálytermen kívüli egyéni fejlesztésröl áthelyeződik a hangsúly a könnyen érthető oktatási segédanyag készítésére, valamint a szaktanárokkal való együttműködésre.

Régóta keresem a lehetséges utakat, hogy az integráció iskolánkban minél eredményesebb legyen, illetve az intézményben folyó nevelés-oktatás egyre inkább az inklúzió felé mutasson. Azt gondolom, hogy olyan új megközelítést mutathatok be, ami mintaként szolgálhat a pedagógusok és a gyógypedagógusok számára.

Az ELTE Bárczi Gusztáv Gyógypedagógiai Karon a gyógypedagógus-szakvizsga szakirányú továbbképzés keretében ismerkedtem meg a könnyen érthető kommunikációval. Ekkor kezdett el foglalkoztatni a gondolat, hogy az iskolánkba járó tanulásban akadályozott tanulók körében is kipróbálom a könnyen érthető kiadványokat. Első lépésként, még a képzés keretében, az akkori csoporttársaimmal közösen készítettük el a természetismeret tantárgy tanulásának segítése érdekében az „Anyagok a környezetünkben” című lecke könnyen érthető változatát, amit ki is próbáltunk. A gyermekek nagyon motiváltak voltak. Az olvasás sikerélményt nyújtott számukra. A szöveg megértéséről feladatlap kitöltésével győződtünk meg. Ekkor 
gondolkodtam el azon, hogy talán még a kifejezetten a sajátos nevelési igényű tanulók számára szerkesztett tankönyvek szövegének a megértése is gyakran problémát okoz. A gyermekek véleménye ebben teljes mértékben megerősített. Ők voltak azok, akik újabb és újabb könnyen érthető kiadványok megírására ösztönöztek.

2017 óta több témában is készítettem könnyen érthető segédanyagokat. Igyekeztem minél több pedagógustársamat bevonni az innovációs folyamatba. Sokan és szívesen próbálták ki a felsőtagozaton tanító szaktanárok közül az elkészült anyagokat. Néhány könnyen érthető oktatási segédanyag témakörének meghatározására már a kollégákkal közösen került sor. Ma már elmondhatom, hogy egyre többen keresnek meg azzal a kéréssel, hogy segítsek egyes tantárgyrészek könnyen érthető átírásában.

A továbbiakban bemutatom az innovációs folyamatnak terepet biztosító általános iskolát. Röviden írok a tanulókról és a pedagógusokról. Ezt követően ismertetem a könnyen érthető oktatási segédanyagok keletkezésének folyamatát. Beszámolok a termékek kipróbálásának tapasztalatairól is. Végezetül szubjektív módon, a fejlesztésben érintett szereplőként értékelem az eredményeket, valamint számba veszem a könnyen érthető kommunikáció további alkalmazásának lehetőségeit.

\section{AZ INNOVÁCIÓS FOLYAMATNAK TEREPET BIZTOSÍTÓ ÁLTALÁNOS ISKOLA BEMUTATÁSA}

Településünk Békés megye csücskében helyezkedik el. A családok többsége alkalmi munkákból, illetve segélyekből él. A szülők - mivel lehetőségeik korlátozottak - ragaszkodnak a helyi általános iskola adta feltételek és lehetőségek kihasználásához. Nem szeretnék gyermekeiket a tölünk 20 km-re lévő, szegregált iskolába járatni. Ha lehetséges, akkor a szülők a helyi általános iskola integrált nevelését-oktatását választják.

Nagyon sok halmozottan hátrányos helyzetủ tanulónk van. A tanulók létszáma 202 fő. Ebből 33 fő (16 százalék) beilleszkedési, tanulási, magatartási nehézséggel diagnosztizált. 28 fő (14 százalék) sajátos nevelési igényű tanuló. Intézményünk egyébként 2005 óta vállalja a sajátos nevelési igényű gyermekek ellátását.

A sajátos nevelési igényű tanulók közül 1 fő mozgássérült, 2 fő tanulásban akadályozott, 25 fönél pszichés fejlődési zavart állapítottak meg. Közülük a 2018/19. tanévben 13 fő tanult eltérő tanterv szerint, az alsó tagozatban pedig 3 fö egyéni tanrend szerint haladt.

Iskolánkban a részleges integráció valósul meg. Ez azt jelenti, hogy csak az iskolában töltött idő egy részében, kizárólag egyes tanórákon vesznek részt a sajátos nevelési igényű gyermekek a többiekkel. A készségtantárgyak tanóráin minden esetben az osztályban vannak. Az eltérő tanterv szerint haladó tanulók évfolyamonként heti 8 órában gyógypedagógus által tartott órákon vesznek részt. Ezeken az órákon többnyire az új ismeretek átadását valósítjuk meg. Az egészségügyi és pedagógiai célú habilitációs és rehabilitációs órák megtartására délutáni időpontban kerül sor.

Az iskolánkban ketten dolgozunk gyógypedagógusként, mindketten együttnevelést segítő szakemberek vagyunk. Azokon az órákon, amikor együtt vannak a sajátos nevelési igényủ tanulók ép társaikkal, a szaktanárok a tanítás folyamatát az egyéni igényekhez illesztve differenciáltan szervezik. A differenciálás mértékét és módját 
a gyógypedagógus és a szaktanár előzetes egyeztetése határozza meg. Tantestületünkre egyre inkább jellemző az integráció szempontjából fontos, a korábbi évekhez képest megváltozott szemléletmód. Nagyon fontosnak tartjuk a differenciálást, illetve a szaktanár és a gyógypedagógus közötti szoros, szakmai együttmüködést. Lényeges, hogy a pedagógusok minden tanulóban a speciális szükségletet, a tanulóra jellemző egyéni sajátosságokat, erősségeket keressék és lássák meg. Alapvető célnak tekintjük, hogy a sajátos nevelési igényű tanulók ne csak jelen legyenek a tanórákon, hanem a tanulási folyamatok aktív részeseivé váljanak.

\section{A KÖNNYEN ÉRTHETŐ OKTATÁSI SEGÉDANYAGOK KELETKEZÉSÉNEK FOLYAMATÁRÓL}

A könnyen érthető oktatási segédanyagok készítésének folyamatát időrendben mutatom be.

Írásom ezen része egyfajta esettanulmány, aminek a célja, hogy a módszertani lépések bemutatása mintaként szolgálhasson az olvasó számára.

Elöször az Anyagok a környezetünkben című oktatási segédanyag készült el az egyetemi képzésben előírt projektmunka követelményének teljesítéseként. Az eredeti szöveget a harmadik osztályos általános iskolás tanulók számára írt környezetismereti tankönyvből vettük.

Ezt követően tizenegy könnyen érthető oktatási segédanyagot készítettem még.

Az első, önállóan készített könnyen érthető tananyag akkor született meg, amikor az egyik magyar nyelv és irodalom szakos tanárnő az iskolánkban készült a minősítő értékelésére. Az akkori csoportjában volt 3 fő tanulásban akadályozott tanuló. Itt szeretném megjegyezni, hogy a tanulásban akadályozott tanulóink egy része az általános iskolás tanulók számára írt tankönyvböl tanul. Vannak olyan tanulásban akadályozott tanulók is, akik a számukra készített tankönyvekből sajátítják el az ismeretanyagot. Azt, hogy melyik gyermekcsoport melyik tankönyvet használja, mindig az osztályban tanító pedagógusokkal egyeztetjük, figyelembe véve a a tanulók képességi szintjét. Természetesen ez sokkal nagyobb összhangot, több egyeztetést igényel a szaktanár és a gyógypedagógus között az egész tanítási folyamatban. A tanárnő segítséget kért tőlem, miként tudná az órán a differenciálást, az egyéni segítségadást megvalósítani olyan módon, hogy az a lehető leghatékonyabb, legösztönzőbb legyen a gyermekek számára az órák folyamán. A tanárnő már látta az előzőleg elkészült könnyen érthető oktatási segédanyagot. Ezért ez a lehetőség is felmerült benne. Egyeztettük a témát, az óra célkitüzését. Ő adta a magyar irodalmi szakmai tudást, én pedig ehhez próbáltam illeszkedni gyógypedagógiai szemléletemmel, tudásommal. Így készült el Radnóti Miklós élete és a „Nem tudhatom” című versének elemzése könnyen érthetően. A nyelven belüli fordítás alapját részben a 8. évfolyamos tankönyvi szöveg képezte, részben az interneten kerestem meg a pontos életrajzi adatokat. Ugyanakkor a vers eredeti formában került a szövegbe, mert álláspontom szerint verset nem érdemes könnyen érthető nyelvi szintre fordítani: így ugyanis elvesztené eredeti szépségét. Versek esetében inkább a vers egyfajta értelmezését lehet könnyen érthetően elkészíteni. A könnyen érhető anyag 
felhasználásával megtartott óra a pedagógus elmondása alapján sikeres volt. A tanulók a tölük elvárható mértékben voltak részesei a tanítási folyamatnak. Az akkor elkészült Radnóti-segédanyagot a későbbiekben is használta a tanárnő.

A magyar szókincs témakört átfogó könnyen érthető segédanyag is a fent említett tanárnővel való közös munka eredménye. Tanév vége felé beszélgettünk arról, hogy a magyar nyelv tantárgyban mi az a mindennapi élethez köthetö témakör, ami a tanulásban akadályozott, 8. évfolyamos tanítványaink szempontjából is kiemelt fontossággal bír. Ekkor jött az ötlet, hogy az általános iskolások számára készült tankönyvben szereplő, a magyar szókincsről szóló szöveget jó volna ismét könynyen érthető módon a gyermekek számára átírni. A munka folyamata az előző közös munkánkhoz hasonló volt. A lényeges információkat közös megbeszélés alapján határoztuk meg. Ezt követően átírtam a szöveget, majd a könnyen érthető szöveg első változatát közösen értékeltük. A tanulóknak ekkora már szinte természetes volt, hogy könnyen olvasható szöveget olvasnak és értelmeznek.

A Tóték és a Tündér Lala könnyen érthető változatának keletkezése kissé eltér az eddig leírtaktól. A fejlesztő órámon a tanítványaimmal az iskolai szintű hangos olvasás felmérésére készültünk. Ekkor fogalmazták meg maguk a tanulók az igényüket, hogy olyan szöveget szeretnének olvasni, mellyel képességeiknek megfelelően tudnak boldogulni. Elmondták azt is, hogy nem szeretnének rossz jegyet kapni, de nem szeretnének kirekesztődni sem a mérésből. A beszélgetés után egyértelművé vált, hogy ez a mérés bizony érzelmileg is nagyon megterhelő nekik. Mi, felnőttek sem szeretünk olyan helyzetbe kerülni, amikor már elöre tudjuk, hogy az az adott tevékenység kudarcos lesz számunkra. Ekkor gondoltam arra, hogy ezt megbeszélem az iskola vezetőségével, illetve a mérésben érintett pedagógusokkal. A cél az volt, hogy a tanulók részeseivé válhassanak a mérésnek. Ennek érdekében az eredeti szöveget, amit a mérés során a normál fejlődésmenetű gyermekek olvasnak, átírtam könnyen érthető szöveggé. Azért választottam az átíráshoz ugyanazt a szöveget, hogy a gyerekek ne megkülönböztetettként vegyenek részt a mérésben, hiszen azonos tartalmú szöveg olvasását várják el tölük is.

A pedagógiai programunkban megjelenő intézményi értékelési rendszer tartalmazza, hogy minden tanév végén, minden évfolyamon, szummatív mérést kell tanulóinkkal végezni a szövegértés területén is. Ezt a mérést a szakmai munkaközösségek irányítják, a felső tagozaton a humán munkaközösség vezetője koordinálja a szövegértés-felmérés tartalmát is. Ennek a mérésnek azért is nagy a jelentősége, mert képet mutat a tanítás-tanulás hatékonyságáról. Ugyanakkor alkalmat ad arra, hogy a tanulók egyéni eredményeit korábbi teljesítményeikhez viszonyítsuk. Így született meg az a gondolat, hogy - a munkaközösség vezetőjével egyeztetve elkészüljön a 6. évfolyamon a szövegértést felmérő feladatsor könnyen érthető változata. A szöveg kiválasztásakor és a feladattípusok meghatározásakor az egyik fő cél az volt, hogy a gyermekek munkavégzése beleférjen a 45 perces időkeretbe. A szöveg választásában még azt is szem elött kellett tartanom, hogy abban a tanévben elvárás volt, hogy lehetőleg ismeretterjesztő szöveg felhasználásával történjen a mérés. Ezért az adott ismeretterjesztő szöveget rövidebben fogalmaztam meg, illetve a szöveg átírása során a könnyen érthető kommunikáció módszertanát is figyelembe vettem. A feladattípusok kiválasztásában a fő szempontom az volt, hogy az értékelés után meg tudjak győződni arról, hogy a gyermekek képesek az olvasást felhasználni az információszerzésre, a lényeget meg tudják ragadni, tudnak össze- 
hasonlítani, értelmezni, elemezni. A szöveg egy foglalkoztató munkafüzetben volt fellelhető, a feladatokat az érintett tanulók képességeinek megfelelöen válogattam össze. Így született meg A farkasok, valamint a hozzá tartozó feladatlap könnyen érthető változata.

A következő könnyen érthető termék már a 2018/2019. tanév elején készült. A 8. évfolyamra négy tanulásban akadályozott tanuló járt. A történelem tantárgy tanulását segítő segédanyag A világ az 1920 -as és 1930 -as években, illetve A második világháború utáni történelem címmel készült el. Ez a könnyen érthető oktatási segédanyag egy teljes történelmi témakört dolgoz fel. Ennek a szövegnek a fordítása volt a legtöbb időt igénylő munka, elsősorban a terjedelme miatt. Nagyon sok szakmai egyeztetésre volt szükség a történelem szakos tanárnővel. Ezért úgy döntöttünk, hogy a gyermekek minden órán megkapják az adott tananyaghoz kapcsolódó részt. A szakos tanárnő a tantárgyi tudását adta, én pedig már bátrabban mertem érvelni a könnyen érthetően szerkesztett mondatokat, fogalomleírásokat illetően. Tulajdonképpen részekből alakult ki az egész. A folyamat végén, a rendszerezéskor, az összefoglalás során lett teljes a gyermekek számára a fejezet. $A z$ elkészült írásokat folyamatosan lefüzték egy mappába. A szöveg a 8. osztályos, általános iskolai történelem tankönyv alapján készült el, a térképek és a képek az internetről származtak.

Az óceánok és tengerek című könnyen érthető oktatási segédanyag egy szakmai segítségkérés eredményeként született. A 7. évfolyamon három tanulásban akadályozott tanuló tanul a számukra készített tankönyvekből. Az ezen az évfolyamon tanító földrajz szakos tanár ebben a tanévben kezdte meg a munkáját intézményünk felső tagozatán, ekkor ismerte meg az általa tanított gyermekcsoportot. Az integrált nevelés-oktatás hatékony megvalósítása érdekében már többször kért tanácsot tőlem. A belső önértékelés folyamatában az adott tanévben került sor arra, hogy a kolléga óráját értékeljék. Nagyon tanácstalan volt abban, hogy miként tudja leginkább bevonni az érintett tanulókat a többi tanulóval egyidejüleg a tanulási folyamatba. Mivel a bemutató órára tervezett témakör a három tanuló tankönyvében nem szerepelt, ezért úgy gondoltuk, hogy a legjobb lenne, ha ők is a többiekkel azonos időben olvashatnák a témát leíró szöveget. A fordítás alapját itt a 7. évfolyamos földrajz tankönyv szövege képezte.

A következő könnyen érthető termék a Testünk és egészségünk, illetve az ehhez a témakörhöz tartozó feladatlap. A 4. évfolyamon tanító kolléganőm kért tanácsot azzal kapcsolatban, hogy miként kérje számon a tanulásban akadályozott tanulóktól a megtanított tananyagot. Az integrált oktatásban már volt tapasztalata, de bevallása szerint a számonkérés módja, a felmérők feladatainak differenciálása némi bizonytalanságot okozott számára. Különösen azért, mert az egyik kislánynak nagyon nehezen ment az olvasás, a feladatok értelmezésében bizonytalannak tủnt, sok segítséget igényelt. Ezért döntöttünk úgy, hogy a 4. évfolyamos tankönyv szövegét átírom könnyebben érthetőre.

A 2019/2020-as tanév elején felmerült bennem a gondolat, hogy ne csak egyes tananyagrészek könnyen érthető változatát készítsük el, hanem oktatási segédanyagként, az érintett szaktanárral egyeztetve próbáljuk meg az általános iskolások számára íródott ötödik évfolyamos történelem tankönyv egészét könnyen érthetővé tenni. Ezt a munkát el is végeztük. Ugyanakkor az anyagot ebben a tanévben ismét át kell dolgozni az új NAT-tal együtt megjelent, annak megfelelő ötödik 
osztályos történelem tankönyvre tekintettel. Nagyon sok szakmai egyeztetésre volt szükség a történelem szakos tanárnővel. Ezért úgy döntöttünk, hogy a gyermekek mindig az aktuális órán kapják meg az adott tananyaghoz kapcsolódó részt. Ebben az innovációban a tudásmegosztás szintén kétirányú volt: a történelem szakos tanárnő a tantárgyi tudását adta, én pedig érvényesítettem a segédanyag írásakor a könnyen érthető kommunikáció szabályrendszerét. A segédanyagot folyamatosan igazítottam, javítottam. A készítés folyamatáról elmondható, hogy részekből alakul ki az egész: vagyis az egyes témakörök végén, a rendszerezéskor, az összefoglalás során lesz teljes a gyermekek számára az adott fejezet. Az elkészült írásokat folyamatosan lefüztük egy mappába. A szöveg (ahogy említettem is) az ötödik osztályos, új történelem tankönyv alapján készült, a térképek, képek részben tankönyvből, részben internetről származnak. Az elkészült munkából egy fejezet a tanulmány mellékletét képezi (1. sz. melléklet). Nagy örömömre szolgál, hogy a könnyen érthető oktatási segédanyag használata a történelem tanórán mára iskolánkban intézményi jó gyakorlattá vált.

\section{A KÖNNYEN ÉRTHETŐ OKTATÁSI SEGÉDANYAGOK ALKALMAZÁSÁNAK TAPASZTALATAI}

Ebben a fejezetben azokról a tapasztalatokról szeretnék számot adni, amelyeket a könnyen érthető oktatási segédanyagok felhasználása során szereztünk. A tapasztalatokról az innovációs folyamatban közvetlenül részt vevő pedagógusokkal és a tanulókkal beszélgettem. Részt vettem továbbá néhány olyan órán, ahol a szaktanárok beépítették a könnyen érthető oktatási segédanyagokat a tanítási óra folyamatába. Az így szerzett tapasztalatok természetesen teljesen személyesek, és nem egy tudományos kutatás eredményei.

A szaktanárok korábban nem ismerték a könnyen érthető kommunikáció módszerét, a könnyen érthető kiadványokról sem volt előzetes ismeretük. A közös munka során sokszor kiemelték a partnerség, a közös gondolkodás, az együttmüködés fontosságát, ami véleményünk szerint növeli az integrált nevelés-oktatás hatékonyságát. A szakoktatókat örömmel és elégedettséggel töltötte el, hogy az innovációs folyamatnak maguk is részesei voltak. Nem egy kész terméket kaptak, hanem szaktudományos ismereteikkel maguk is hozzájárultak az oktatási segédanyagok készítéséhez.

Egyes pedagógusok szerint a könnyen érthető oktatási segédanyagok sikeres alkalmazásához szükséges az osztálytársak toleráns hozzáállása is.

Lényegesnek találták, hogy a tanulókat sokkal könnyebben tudták bevonni az órai munkába. A tanulókat könnyű volt motiválni, szívesen használták a könnyen érthető tananyagot. Úgy tủnt, hogy nem volt zavaró, hogy nem a megszokott tankönyvet használták. A pedagógusok szerint érezhetően és pozitívan változott az olvasáshoz való hozzáállásuk, a szereplési aktivitásuk, a magabiztosságuk növekedett. Kevesebb gátlás jellemezte a tanulók olvasását. Az érintett diákok mertek hangosan olvasni. Még az a gyerek is vállalta a hangos olvasást, akit eddig erre nem lehetett rávenni tanórai keretek között. A tanulók szívesen olvasták a számukra is érthető 
segédanyagokat, mert egyszerű és rövid mondatokkal találkoztak a szövegben. Kiemelték, hogy valószínüleg a betűméret és a sorok hossza is megkönnyíthette az értő olvasást. A szaktanárok többsége úgy tapasztalta, hogy a magyarázó erejü, tehát nem illusztrációs célú képi támogatás is elősegítheti a megértést.

Az integrált oktatás során nem csak az egyéni feladatok végzésében voltak aktívak az érintett tanulók, hanem a frontális osztálymunkában is tevékenyebben vettek részt.

Úgy tünik, hogy a könnyen olvashatóan szerkesztett tananyag olvasása, a könynyen érthetően megszövegezett üzenet megértése sikeresnek bizonyult, hiszen az olvasott információkat megértették. A gyerekek magabiztosabb olvasása pozitív hatással lehet a memorizálás folyamatára is.

Többek szerint az érintett diákok kifejezetten örültek a rájuk szabott figyelemnek és törődésnek.

A könnyen érhető oktatási segédanyagból megtanult ismeretek számonkérése többféle módon történt. Így például akár könnyen érthetően szerkesztett dolgozat formájában is adhattak számot a tudásukról. Minden kolléga arról számolt be, hogy a számonkérés ezen módja sikeresebbnek és eredményesebbnek bizonyult a korábbiaknál. A gyerekek sikeresebben tudtak felkészülni a könnyen érthető oktatási segédanyagokból a szóbeli feleletre, illetve a dolgozat megírására.

Összességében úgy tünik, hogy a könnyen érthető oktatási segédanyagok jól beilleszthetők az intézményben folyó integrált nevelési-oktatási folyamatba. A tanulásban akadályozott tanulók is ugyanazt a tananyagot tanulhatják, mint az osztálytársaik, csak számukra hozzáférhető és értelmezhető formában. Ez a módszer azért is hatékony, mert a tanulók aktív résztvevői válnak az óráknak, és a tudáspróbák teljesítése is több sikerélményt okoz mind a tanulóknak, mind pedig a szaktanároknak.

A könnyen érthető kommunikáció módszere a kollégák többsége szerint nem csak a tanulásban akadályozott tanulók esetében hasznos. Az osztályba járó, de alacsonyabb nyelvi kompetenciájú tanulókkal is jól tudják alkalmazni.

\section{A TANULÓK VÉLEMÉNYÉRŐL}

1. „A képek segítettek.”

2. „A könyvben a szó nagyon hosszú és nehéz."

3. „Amit nem annyira bírtam kiolvasni, abban segített a tanító néni."

4. „Azért volt könnyü, mert a végén is emlékeztem arra, amit az elején olvastam.”

5. „Elolvastam és jelentkeztem.”

6. „Izgultam a felmérőnél, mert nem tudtam, hogy milyen lesz. Megörültem, hogy könnyü, nem olyan nehéz, mint a többieknek."

7. „Jó, hogy legalább már meg tudom csinálni."

8. „Jó, mert kevesebb volt a lap, nagyobb a betű."

9. „Könnyebb volt, mert ha egyszer is elolvastam, megértettem.”

10. „Könnyebben elolvastam a feladatokat.”

11. „Könnyebben értelmezhető volt.”

12. „Könnyebben lehetett készülni és megtanultam.”

13. „Könnyü, mert rövidebb volt, jobban lehetett érteni."

14. „Nagyobb bennük a betük, meg a képek is jók.” 
15. „Nem kellett kikeresni, mert ki volt írva a fontos.”

16. „Nem olyan kicsik a betűk, meg hogy jól ki lehetett olvasni, mert nem egybe voltak."

17. „Órákon is figyeltem, meg a szövegből megtanultam."

18. „Rövidebb mondatok voltak.”

\section{ÖSSZEFOGLALÁS}

A tanulmányban bemutatott innováció egyik fö eredményének tekintem, hogy iskolánkban összesen 12 darab könnyen érthetöen szerkesztett tananyagból 13 tanulásban akadályozott tanuló 5 különböző szakos pedagógus segítségével tanulhatott a tárgyalt másfél év alatt. Úgy érzem, hogy ez a fejlesztés közvetlenül hozzájárulhat az érintett gyerekek önérvényesítéséhez, közvetve pedig az integráció eredményesebb megvalósulásához.

Minden embernek, így az oktatásban részt vevő tanulásban akadályozott tanulóknak is demokratikus joguk, hogy hozzáférhessenek az információhoz. Ezért is tartom nagyon fontosnak, hogy legyenek könnyen érthető oktatási segédanyagok. Azt gondolom, hogy ezzel biztosítható az oktatási folyamathoz való egyenlő esélyű hozzáférés a sajátos nevelési igényủ gyermekek és tanulók számára.

Bízom abban, hogy a könnyen érthető kommunikáció hangsúlyossá válhat az integrált nevelés-oktatás folyamatában.

Ez a fajta innováció pozitív hatással lehet a szakmai párbeszédre a helyi közösségünkben. Ebben a folyamatban mindenkinek jut szerep. Valódi team-munka alakulhat ki.

Egyéni szinten hozzájárulhat a tipikus fejlődésmenetủ tanulók toleranciájának és empatikus viselkedésének megerösödéséhez.

Különösen fontosnak tartom, hogy a tanulásban akadályozott tanulók motiválására is alkalmas. Azt gondolom, hogy gyógypedagógusként fontos feladatunk mindent megtenni annak érdekében, hogy az adott osztályba járó minden tanuló megérthesse az őt körülvevő világot.

Remélem, hogy sikerült szemléltetni, milyen nagy lehet a jelentősége ennek az innovációs folyamatnak egy falusi iskolában.

Tanulmányomat egy témához illő idézettel szeretném zárni:

„Az egyik leghatékonyabb dolog, amit tehetünk, hogy hallgatunk gyermekeinkre és megtaláljuk az utat egyedi képességeik támogatására.

Ha megadjuk gyermekeinknek a magabiztosságot, azzal segithetünk nekik sokkal teljesebb életet élni, és lehetővé tesszük, hogy gazdagabbá tegyék maguk körül a világot."

(Mallika Chopra: 100 ígéret gyermekemnek) 


\section{MELLÉKLET}

\section{Az ókori Görögország öröksége}

\section{A görög föld múltja}

Az ókori görög törzsek a Balkán-félszigetre vándoroltak.

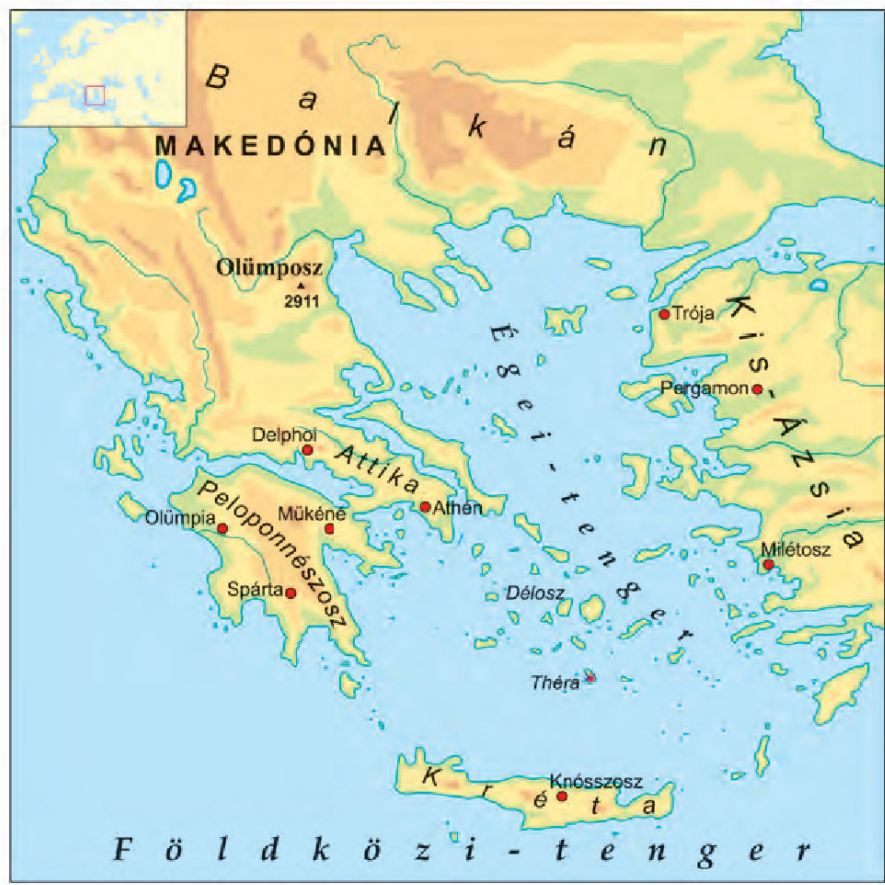

A múltat az épületek romjai, és a mítoszok is őrzik.

A mítoszok istenekről, különös képességekkel rendelkező hősökről szólnak. A mítoszok fontos történelmi források. 


\section{A trójai háború története}

Az istenek lakodalmat tartottak.

Minden isten és istennő meg volt hívva.

A veszekedés istennőjét nem hívták meg.

A veszekedés istennője megharagudott.

Egy almát gurított a mulatozó nép közé.

Az alma aranyból volt.

Az almára azt a szót írta,

hogy a legszebbnek.

3 istennő összeveszett az almán.

A főisten tanácsára Trója királyának kellett igazságot tenni.

A főistent Zeusznak hívták.

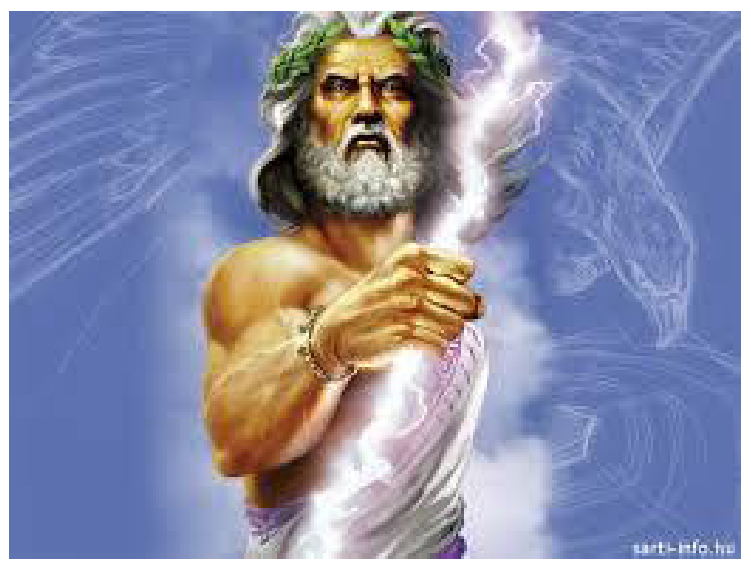

A 3 istennő ajándékot akart adni az almáért a királynak.

Az egyik istennő hatalmat ígért.

A másik istennő bölcsességet ígért.

A harmadik istennő a legszebb nő szerelmét ígérte. 
A király a legszebb nő szerelmét választotta.

A legszebb nő azonban a spártai király felesége volt. A szerelem istennője segített Trójába szöktetni a nőt.

A spártai király nagyon haragudott, ezért megtámadta Tróját.

\section{A trójai faló mondája}

A trójai háború 10 évig tartott, egyik fél sem tudott győzni.

A görög király,

Odüsszeusz cselt eszelt ki.

Azt találta ki,

hogy építsenek egy nagy falovat.

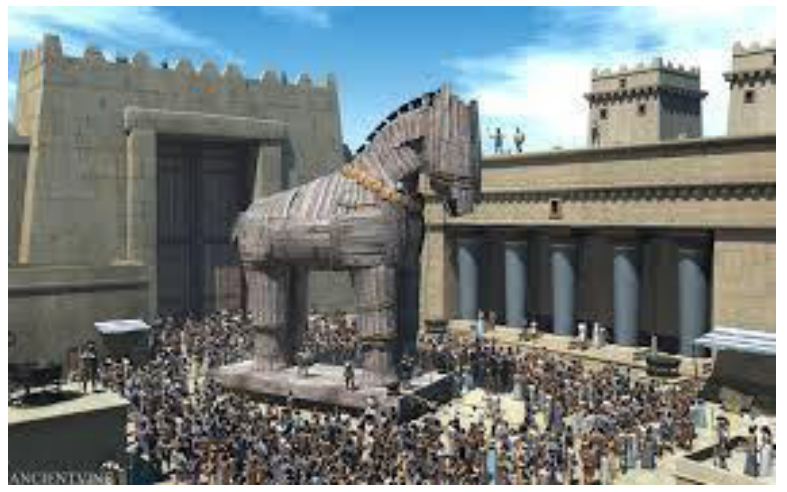

A faló belsejébe elbújtak a legügyesebb katonák.

A többi katona hajóval elment.

A trójaiak bevonták a falovat a várba.

Éjszaka a katonák előbújtak a falóból.

Beengedték a várba a visszajött görög katonákat.

Ezzel a csellel nyerték meg a görögök a harcot. 


\section{A görögök vallása}

Az ókori görögök több istenben hittek.

Tizenkét fontos görög isten volt.

$\mathrm{Az}$ istenek az Olümposz hegy csúcsán laktak.

Minden istennek feladata volt.

A föisten Zeusz volt.

Zeusz volt az istenek királya.

Zeusz volt az istenek és az emberek atyja.

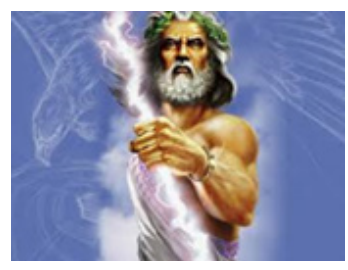

Zeusz testvére Poszeidon.

Poszeidon a tengerek istene.

Az alvilágnak is volt istene.

Az alvilág istenét Hádésznak hívják.

Zeusz lánya Pallasz Athéné.

Pallasz Athéné a bölcsesség

és a művészet istennője.

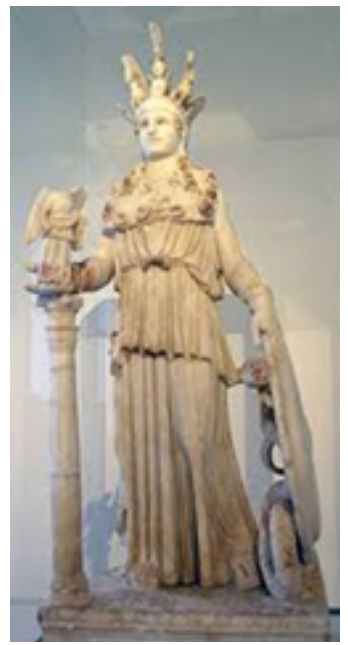

A görög nép fontos kérdésben az istenek tanácsát kérte. 


\section{A dicső Athén}

A görög törzsek egyre nagyobb területen laktak.

Nagyon sok független városállam alakult ki.

Athén és Spárta voltak a legjelentősebb városállamok.

Athén a Balkán félszigeten,

Attikán található.

Athénban olajfaligetet és szőlőt telepítettek.

Athénból sok olajat

és bort szállítottak.

A bort és az olajat

kereskedelmi hajókon

szállították.

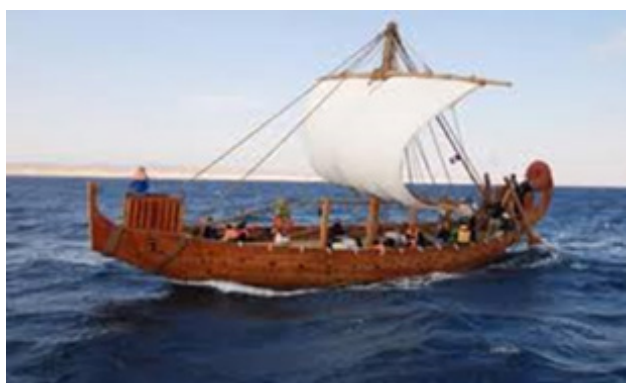

Az athéni iparosok híresek voltak.

Nagyon híres iparosok voltak a fazekasok.

A fazekasok vázákat is készítettek.

A fazekasok edényeket is készítettek.

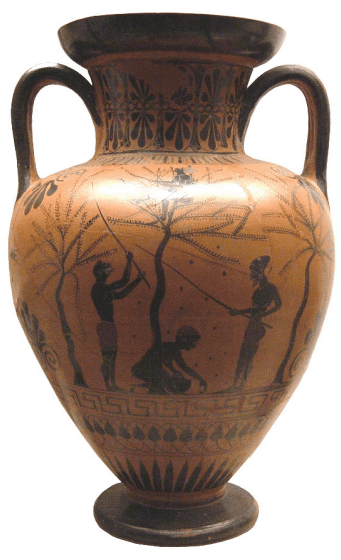




\section{Spárta és a spártai nevelés}

Spártában a szabad polgárok kevesen voltak.

Az őslakók elnyomott emberek voltak.

A hegyvidék lakosai voltak a körüllakók.

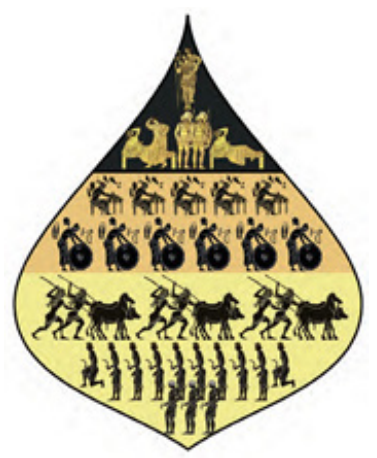

A spártaiak legfontosabb foglalkozása a katonáskodás volt. A katonás életmód szigorú törvények szerint zajlott.

A törvény szerint a szabad spártai családoknak egyformán volt vagyonuk.

Az újszülött fiú gyermeket a város vezetőjének kellett bemutatni. Az erős csecsemő életben maradt.

Felnőttként jó katona lett.

Ha betegesnek tartotta a vezető a csecsemőt, akkor magára hagyták.

A magára hagyott csecsemő meghalt.

A fiúk 6 éves korig éltek a családban. 6 éves koruk után katonai táborban éltek. 20 éves korukban a hadsereg tagjai lettek. 


\section{A görögök összetartozása}

A görög államok egymástól független államok voltak.

Ezeket az államokat városállamoknak nevezzük.

A városállam görög neve polisz.

A görögökben erős volt az összetartozás tudata.

Az összetartozást három dolog erősítette.

Ez a három dolog a közös nyelv,

a közös vallás és a katonai szövetség volt.

\section{Az olimpiai játékok}

Zeusz tiszteletére ügyességi versenyeket rendeztek.

Az olimpiai játékok nagyon híresek voltak.

A győztesek nevét írásokban is feljegyezték.

Az olimpiai játékokat négyévente rendezték meg.

Az olimpiai versenyen minden görög férfi részt vehetett.

A nők még nézőként sem vehettek részt a versenyen.

Az olimpia idején nem lehetett háború.

A verseny első napján ünnepséget rendeztek. 
Az olimpia fő versenyszámai:
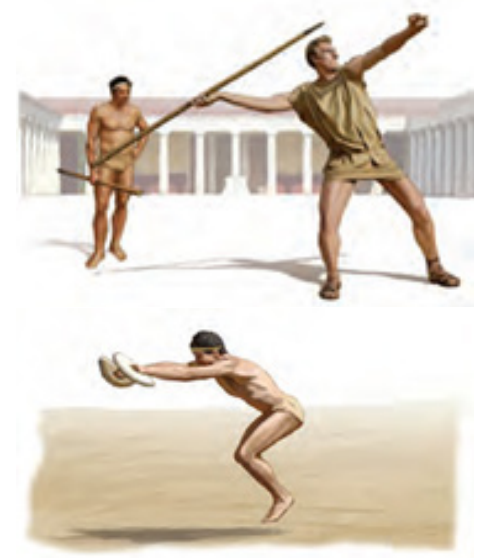

a kocsiverseny,

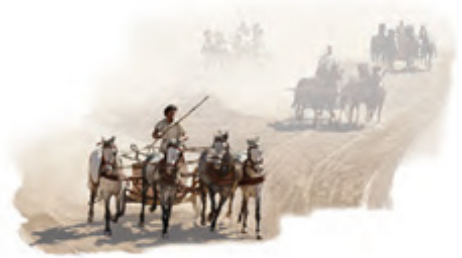

az öttusa,

a futóverseny,
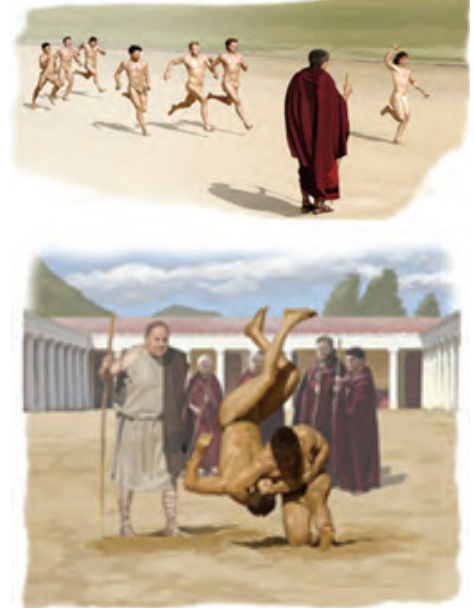

az ökölvívás.

Az olimpiai győztesek jutalma a koszorú volt. A koszorút a szent olajfa ágából fonták.

Az ókori sportjátékokat Olümpiában rendezték meg. 